\author{
V International Forum on Teacher Education
}

\title{
Study of Functional Mechanism of Technological Teacher Training Update
}

\author{
Valerian F. Gabdulkhakov*
}

Kazan Federal University, 420008, Kazan (Russia), 18 Kremlyovskaya street

\begin{abstract}
The problem of the study is in the fact that the organizational and pedagogical teacher training mechanisms at the universities do not always have a positive effect on the quality of the pedagogical education. The objective of the study was to develop a functional mechanism for technological teacher training update at the university. The methodology is based on the concept of key competence of Gary Hamel, associated with the development of management strategies based on a matrix of significant problems. A significant problem matrix was obtained, on the basis of which it was concluded that the functional mechanism for technological update is an organizational and pedagogical system that implements such functions as diagnostic monitoring, conceptualization, informatization and gamification, systematization and classification, forecasting and synergy, reflection, feedback, continuity. The significant problem matrix allowed to substantiate the relevance of using the certain technologies in the functional mechanism (systemtarget technology, structural and content technology, personalized technology, distributed technology, integrative technology, menter-technology, genius-technology, education gamification technology, innovative culture formation technology, foresight technology, pedagogical facilitation technology, noxological technology), criteria (personalized accentuation, cognitive accentuation, activity accentuation, employer's satisfaction with training outcomes). The implementation of the functional mechanism at Kazan Federal University ensured the growth of the future teachers' professional competence. The results obtained in the course of the study allowed to formulate the recommendations for the use of the functional mechanism for technological teacher training update at the universities.
\end{abstract}

Keywords: functional mechanism, pedagogical education, technology, university, teacher training.

\section{(C) 2019 Valerian F. Gabdulkhakov}

This is an open access article distributed under the terms of the Creative Commons Attribution License (CC BY 4.0), which permits unrestricted use, distribution, and reproduction in any medium, provided the original author and source are credited.

Published by Kazan federal university and peer-reviewed under responsibility of IFTE-2019 (V International Forum on Teacher Education) 


\section{Introduction}

The current state of pedagogical education causes alarm of the world public: the current teacher training system has faced new challenges - the transformation of socio-economic, regulatory and legal relations in the structure of pedagogical education, the public consciousness transformation in a change in attitudes towards school, teacher, child and childhood, the education space transformation - the need to use modern digital technologies in studies, effective forms of personification, gamification of learning, personal (reflexive) form of a network or remote communication.

\section{Purpose and objectives of the study}

The problem of creating a functional mechanism that allows to quickly update not only the curriculum content, but also educational technologies, has become increasingly relevant in recent years. The quality of education, the quality of training, and the ranking of universities depend on the timely updating of technologies.

The study set to decide how to develop the organizational and pedagogical functional mechanism providing the technological updating of teacher training at the university based on the analysis of the problems of technological equipment of teacher training at the university and special pedagogical experiments at the schools, colleges, universities and centers for continuous pedagogical education.

Research questions are (1) how to solve the problem of developing a technological updating mechanism at the universities of Russia, Eastern Europe, Western and Northern Europe; (2) what are the functions of organizational and pedagogical mechanisms in the structure of pedagogical education development; (3) what criteria, indicators, and methods to use when diagnosing students' professional competencies; (4) how the functional model of technological updating affects the development of students' professional competencies.

The research objective is to develop a functional mechanism for technological teacher training update at the university. We investigated the functions of organizational and pedagogical mechanisms for updating the technological content of teacher training.

\section{Literature review}

The researchers of pedagogical technologies for teacher training in the Russian universities (Torgunskaya, 2007; Shumilova, 2009; Loktyushina, 2011; Ivochkina, 2012; Mardakhaev, Nikitina, 2012; Mityaeva, Fomina, 2016; Konoplyanskiy, 2018) and the Eastern, Western and Northern European countries (Cunningham, 2010; Gay \& Howard, 2010; Weber, 2014; Hsu, Hamilton, \& Wang, 2015; McMahon, Forde, \& Dickson, 2015; Menter, 2015; Root-Bernstein, 2015; Darling-Hammond, 2016; Xin, Accardo, Shuff, Cormier, \& Doorman, 2016; Barnes \& Mattson, 2017) pay attention to the organizational and pedagogical mechanisms of education development, innovation management, education quality management.

At present, the education development mechanisms, updating its content are understood as a package (or system) of measures, assembly of elements, processes, functions, etc. that realize the object's ability to function, develop, ensure the synergistic effect and effectiveness of the educational process.

These mechanisms suggest:

- the systemic changes due to internal innovations in objectives, content, technologies;

- the educational process technologization, aimed at increasing the creative and exploratory activity of the educational process subjects, their self-realization and professional identity; 
- the educational process technologization at the university through a change in the organization of the student government bodies' activities, involving the students in the pedagogical, socio-economic, political and cultural life of the university;

- the inclusion of interdisciplinary (integrative) technologies aimed at strengthening the practical orientation of future teacher training into the educational process;

- the growth of social and professional initiatives that are associated with the involvement of the public in the actual university management.

As you can see, the technologies are actively used in the education development mechanisms and they are associated with the creative and research activity of education subjects, with the educational work organization in the universities, with the strengthening the practical orientation of teacher training, with the growth of social and professional initiatives by teachers and students, etc.

Thus, the educational technologies and the problems of their updating are in the focus of attention of the researchers engaged in the organizational and pedagogical mechanisms.

Indeed, in recent years the education space has become increasingly digital and multichannel. A person entering this space needs the constant assimilation of the new educational technologies. At the same time, the human, personal factor becomes relevant: the student's personality can go to the virtual world, get out of touch with reality, get misplaced in his future professional activity in the conditions of interaction with the digital space. The teacher's personality - the electronic resource author - as a possessor of the future teacher's moral values should interact with the student not only in the distance, but also in the living - real - format. The real interaction format is characterized by: 1) moral and spiritual qualities; 2) equality of communication partners; 3) reliance on the teaching staff (Korpachev, 2018).

From this point of view, the functions of organizational and pedagogical mechanisms are the least studied: the absence of functional (personal, reflexive, prognostic, synergistic, etc.) scope of engagement (teacher and student) in these mechanisms can result in the technological effect loss and the digital (and any another new) pedagogical education discrediting.

\section{Methodology}

The study methodology was based on the concept of 'key competence' by Gary Hamel (2014) related to the development of management strategies based on a significant problem matrix.

The methods of questioning, interviewing, analysis and comparison, methods of summarizing the statistical results, learning outcomes were used in the study.

As a result of processing the data obtained during interviews, four types of problems were revealed (according to the typology of Prigozhin (1995): (1) root - causing or exacerbating other problems; (2) key - depending on some problems, but at the same time causing or exacerbating other problems; (3) resultant - arising from other problems; (4) autonomous - quite significant, but not related to others.

The "+" sign indicated the problems that turned out to be pronounced as of 2013-2018, the "-." sign indicated those problems that exist but cannot be designated as root, key, resultant, autonomous ones. The "+" sign means more positive in solving the problem, the "-" sign means the predominance of the negative in solving the problem.

The Spearman's rank correlation coefficient was used in the study. He made it possible to establish the dependence of the future teachers' professional competence on the degree of implementation of technological updating mechanisms at bachelor, master and postgraduate level.

Thus, a correlation was established - the statistical relationship of several quantities (quantitative indicators of the most repetitive problems), which can be considered root, key, resultant, autonomous 
(Prigozhin, 1995) with some acceptable degree of accuracy. At the same time, the changes in the values of one or several of these quantities are accompanied by a systematic change in the values of other quantities.

\section{Results and Discussions}

According to Prigozhin (1995), we have made a list of problems of technological updating of the pedagogical education content. The experts (pedagogical education organizers) had to cross the irrelevant or repetitive problems, then to combine the problems, when necessary, to select the most important ones from the resulting transformed list. After filling in the 'empty schedule' by the paired comparison method, the main problems of the functional mechanisms for technological teacher training update were identified.

We conducted this study in 2016-2018 at the Universities of Russia (Kazan Federal University, Lomonosov Moscow State University, Mordovian State University, Baltic Federal University); Belarus (A.S. Pushkin Brest State University, Department of Pedagogy of Brest Technical University); Poland (University of Opole, Pope John Paul State University); Moldova (Slavic University of the Republic of Moldova); Germany (Department of Pedagogy of Dresden University of Technology); Norway (University of Oslo), Sweden (Stockholm University).

The technological updating mechanisms at different levels - pedagogical specialized secondary level, general higher pedagogical level, bachelor level, master level, pedagogical postgraduate level and advanced training and retraining levels at universities were analyzed as a part of the study.

Based on the analysis of the matrix data (237 surveyed teachers from the universities of the Russian Federation, Eastern and Western European countries, Scandinavian countries), studying, comparing the root, resultant, key problems, the dominant functions that, according to teachers, should influence the technological updating the teacher training were established (Table 1, Diagram 1).

Table 1. Results of diagnostics of the dominant functions of technological updating the teacher training (in \%)

\begin{tabular}{|c|c|c|c|c|}
\hline Universities & Russ & Eastern & Wester & Scan \\
\hline Functions & $\begin{array}{l}\text { ian } \\
\text { Federation }\end{array}$ & $\begin{array}{l}\text { European } \\
\text { countries }\end{array}$ & $\begin{array}{l}\text { n European } \\
\text { countries }\end{array}$ & $\begin{array}{l}\text { dinavian } \\
\text { countries }\end{array}$ \\
\hline Monitoring & 87 & 43 & 59 & 53 \\
\hline Conceptualization & 79 & 68 & 41 & 39 \\
\hline $\begin{array}{l}\text { Informatization and } \\
\text { gamification }\end{array}$ & 54 & 89 & 95 & 92 \\
\hline $\begin{array}{l}\text { Systematization and } \\
\text { classification }\end{array}$ & 65 & 59 & 56 & 94 \\
\hline Forecasting and synergy & 68 & 78 & 94 & 50 \\
\hline Reflection & 97 & 76 & 91 & 92 \\
\hline Feedback & 82 & 95 & 55 & 52 \\
\hline Continuity & 65 & 77 & 57 & 51 \\
\hline
\end{tabular}

As you can see, the dominant functions at the universities of Russia, Eastern, Western and Northern European countries are determined approximately equally. However, if the monitoring (87\%), reflection (97\%) are at the forefront in Russia, then the informatization and gamification (89\%) and feedback (95\%) prevail in the Eastern European countries. 
It is noteworthy that the universities of the Western and Northern European countries clearly stand out the functions of informatization and gamification (95\%), forecasting and synergistic analysis (Western Europe - 94\%, Northern Europe - 90\%), reflection (Western Europe - 91\%, Northern Europe - 92\%).

Almost all the functions indicated in the Diagram (see Diagram 1) are noted by the majority of teachers (more than $50 \%$ of the respondents). Only the monitoring function in the Eastern European countries is noted as the root problem by $43 \%$ (for comparison, $87 \%$ in Russia). In Eastern European countries, this situation is explained by instability and unpredictability of the university education development.

Such functions as forecasting and synergistic analysis (only 50\%, 94\% in Western Europe, 78\% in Eastern Europe, 65\% in Russia), systematization and classification (94\% versus 56\% in Western Europe or $65 \%$ in Russia) stand apart in the Scandinavian countries (Norway, Sweden, Denmark, Finland).

The reflection is noted at the Russian universities as an important problem of the technological organization of the educational process not only by teachers of psychology and pedagogy, but also by the teachers of basic disciplines (mathematics, physics, chemistry, etc.).

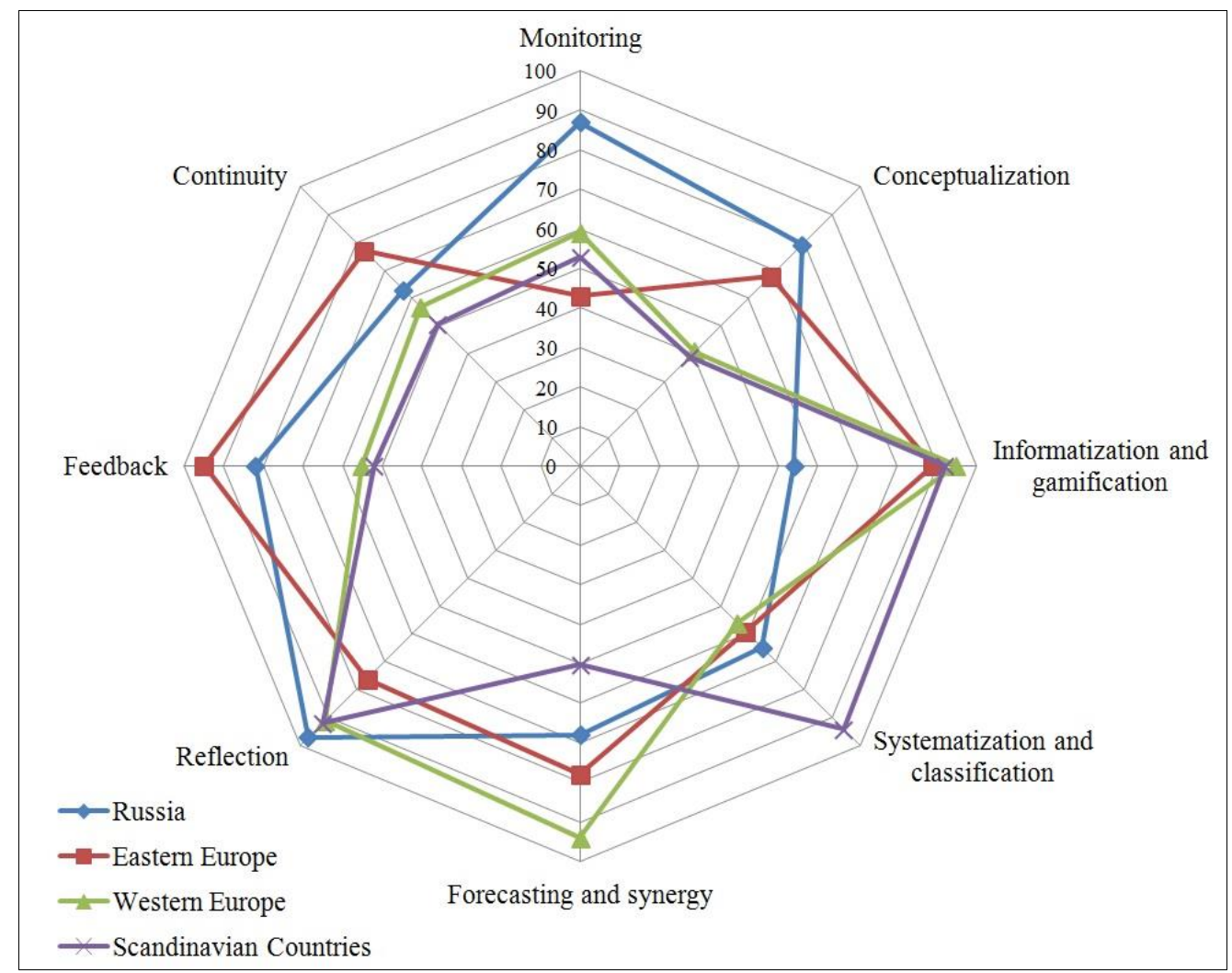

Diagram 1. Results of diagnostics of the dominant functions of technological updating of teacher training in Russia, in the Eastern, Western European countries and Scandinavian countries (in \%)

Despite the wide variation in the respondents' opinions on the need for resuscitation, revival or development of these functions, the obtained diagnostic map (Diagram 1) convincingly shows that the 
functional mechanism for technological teacher training update is of great importance for the teacher education development at the universities.

\section{Pedagogical Experiment at Kazan Federal University}

The study found that the functional mechanism for technological teacher training update should be based on the implementation of the following functions:

system monitoring of technological support of pedagogical education, scientific achievements in the field of fundamental (subject) science (mathematics, physics, chemistry, etc.), in the field of applied science (psychology, pedagogy, methodology), advanced innovative practice (87\% of respondents);

conceptualization of system monitoring data of technological support of the content and system of pedagogical education (79\% of respondents);

informatization and gamification of teacher training technologies (54\% of respondents), systematization and classification of the technological teacher training $(65 \%$ of

respondents);

forecasting and synergistic analysis of technological support of future teacher training (68\% of respondents);

reflection, involving the analysis of technology from the point of view of the student's personal contact with the teacher and the student's self-analysis of the cognitive, moral and ethical sphere of his future professional activity (97\% of respondents);

feedback - analysis of the university's interaction with educational institutions $(82 \%$ of

respondents);

continuity - analysis of technologies from the point of view of the advanced training tasks, professional retraining of educators (63\% of respondents).

Such teacher training technologies as system-target technology, structural and content technology, personalized technology, distributed technology, integrative technology, menter-technology, geniustechnology, education gamification technology, innovative culture formation technology, foresight technology, pedagogical facilitation technology, noxological technology were identified, justified, tested based on the development of a significant (root, key, resultant) problem matrix. The matrix, which summarized the results of 8 Russian and foreign universities, showed that these technologies make pedagogical education personally oriented, practically meaningful and of high quality. These technologies are used in the educational process of Kazan Federal University (and are distributed as a part of the program activities of the IFTE) at the Russian and Western European universities. The university technologies can be used (and are already being used) in the Russian pedagogical education systems (partner universities of Kazan Federal University).

The traditional system of pedagogical education was more focused on humanistic explanatory and illustrative or problematic (heuristic) forms of education. In the 20th century, the young man's education space changed dramatically (it became digital, multichannel and often commercial), the young man changed himself (his operational mosaic thinking became to dominate), the structure of the teacher's and student's interpersonal relations changed (contractual training forms began to influence the relationship), etc. All this required the identification, development of learning technologies that are relevant to time and to teacher training at non-pedagogical university.

The traditional technologies focused on explanatory-illustrative and problem-developing teaching methods made it possible to ensure an adequate level of student training, but did not integrate the subject's 
content at an interdisciplinary level with work at school and practically did not prepare them for work with children (for the teaching methods). The new technologies allowed to maintain a high level of training on the one hand, and to ensure the effective student training for work in the preschool institutions and schools on the other hand: they provide for interdisciplinarity, modularity, digital support, orientation to the future teacher's personality and teaching internship. These technologies can be used in the undergraduate and graduate studies of classical (federal) universities of Russia and foreign countries.

The results of introducing new technologies into the educational practice of Kazan Federal University were the increase in the quality of pedagogical education (based on the results of state examinations, defense of graduation thesis), the employers' feedback, etc.

Functional Mechanism for Technological Teacher Training Update

Such functional mechanism was tested at Kazan Federal University in 2018-2019. To test the effectiveness, the graduate students, young teachers, advanced students (1,243 people) were involved. Such a wide sample made it possible to use the criteria of personalized, cognitive and activity accentuation, comparing the graduate student with a young teacher and a teacher employed during 5-10 years.

The qualification indicators approved by the Order of the Ministry of Education and Science of Russia (Order No. 276, 2014) were used as indicators of the cognitive and practical activities of the respondents.

These indicators - the indicators of the students', teachers', practitioners', advanced students' competence formation - became the basis for testing the effectiveness of the developed functional mechanism (Table 2).

Table 2. Criteria, indicators, methods of monitoring the professional pedagogical competencies of students

\begin{tabular}{lll}
\hline Criteria & Indicators & \multicolumn{2}{c}{ Monitoring Methods } \\
\hline 1. Personalized & A student (teacher) is characterized & - reflexive method,
\end{tabular}
accentuation by the ability to form the students' motivation to implement learning activities. A student perceives the interaction with the students as a personally significant activity and "inspires" an interest in the subject, study and school as a whole. $\mathrm{He}$ is characterized by the motivation for the growth of pedagogical skills determined by the indicators of professional categories the teacher category, the first and the highest qualification categories: he owns the modern educational technologies and methods and effectively apply them in his professional practice.

2. Cognitive The cognitive accentuation is used accentuation

in building the pedagogical education structure and content, preparing the teacher for decision-making in problem situations of involves the self-analysis by a student, a teacher of their own pedagogical, methodical activity (in terms of qualification characteristics indicators);

- expert method, involves the participation of teachers and methodologists, is associated with the analysis of the effectiveness of lessons and extracurricular activities;

- qualimetric method, involves the use of simple mathematical methods for processing the results of 


\begin{tabular}{|c|c|c|}
\hline & $\begin{array}{l}\text { professional activity, giving particular } \\
\text { importance and, accordingly, enhancing the } \\
\text { role of the intellectual component of the } \\
\text { future teacher's activity. } \\
\text { A student (teacher) is characterized } \\
\text { by the maximum (or close to it) level of } \\
\text { development of competence in the field of } \\
\text { personal qualities; he is capable of a } \\
\text { differentiated and individualized perception } \\
\text { of the students' inner world; in order to take } \\
\text { a humanistic attitude towards them during } \\
\text { the educational process. He is characterized } \\
\text { by the professional pedagogical competence } \\
\text { - modern educational technologies } \\
\text { (educational technologies should meet the } \\
\text { basic requirements: conceptuality; } \\
\text { consistency; manageability; efficiency; } \\
\text { reproducibility), etc. }\end{array}$ & $\begin{array}{l}\text { educational and methodical } \\
\text { work; }\end{array}$ \\
\hline $\begin{array}{cc}3 . & \text { Activity } \\
\text { accentuation } & \end{array}$ & $\begin{array}{l}\text { The productivity and effectiveness } \\
\text { of methodological activities (speeches at } \\
\text { scientific conferences, pedagogical readings, } \\
\text { seminars, sections, etc.; conducting } \\
\text { demonstration lessons, classes, events, } \\
\text { master classes, etc.; scientific, } \\
\text { methodological and academic publications } \\
\text { (publication availability); stable results of } \\
\text { learning by students, pupils of educational } \\
\text { programs and indicators of the dynamics of } \\
\text { their achievements above the average in the } \\
\text { subject of the Russian Federation, etc. }\end{array}$ & $\begin{array}{l}\text { - sociological method, } \\
\text { involves the use of } \\
\text { questionnaires in order to } \\
\text { identify the objective state of } \\
\text { motivation of pedagogical } \\
\text { activity, interest in educational } \\
\text { technologies, striving for the } \\
\text { pedagogical activity efficiency, } \\
\text { employers' satisfaction with } \\
\text { the quality of teacher training. }\end{array}$ \\
\hline $\begin{array}{l}\text { 4. Employer's } \\
\text { satisfaction with training } \\
\text { outcomes }\end{array}$ & $\begin{array}{l}\text { The level of the employers' } \\
\text { satisfaction with the quality of teacher } \\
\text { training. The number of points for each } \\
\text { indicator (the points are not cumulative) is } \\
\text { 0-100-150. Productivity and efficiency of } \\
\text { educational activities: } \\
\text { 1. The share of students who } \\
\text { showed the average or above regional } \\
\text { results (average data for the inter- } \\
\text { certification period) according to the final }\end{array}$ & \\
\hline
\end{tabular}


certification results.

2. The share of students who have achieved " 4 " and " 5 " over the past three years as a result of external control. Diagrams, graphs and other documents confirming the knowledge quality dynamics 0-50-100-200.

3. The results of the students' participation in the subject quizzes. Availability of certificates, diplomas or other documents of medalists and winners of competitions 0-10-40-80-100-120-150, etc.

The implementation of the functional mechanism for technological updating based on the specified criteria and indicators (Table 2, criterion 4) affected the quality of the pedagogical education:

the satisfaction with the teachers' and students' educational process;

the growth of the indicators of the pedagogic profession choice among pupils, students of colleges and universities;

the growth of the number of exemplary students;

the satisfaction of employers (heads of educational institutions) with the quality of teacher training at college and university;

the growth of the number of students and teachers participating in pedagogical skill competitions and involved in innovative scientific and methodological activities.

One of the important indicators of the quality of pedagogical education was the level of the future teacher competence formation. The competence structure can be measured by diagnosing three accentuations: cognitive (knowledge and understanding), activity (practical and operational knowledge application), personal (personal qualities, attitudes, value orientations) (Bloom, 1956).

342 students of Kazan Federal University took part in the accentuation diagnosis experiment in 2018 (Table 3). Various tools were used to diagnose the accentuations - the future teacher competence level:

to diagnose the expertise, knowledge and skills - the tests of open and closed type;

to diagnose the skills - logical and practical tasks;

to diagnose the expertise (automated skills) - cases with real pedagogical situations.

Table 3. Accentuation of the students' professional competences before and after the experiment

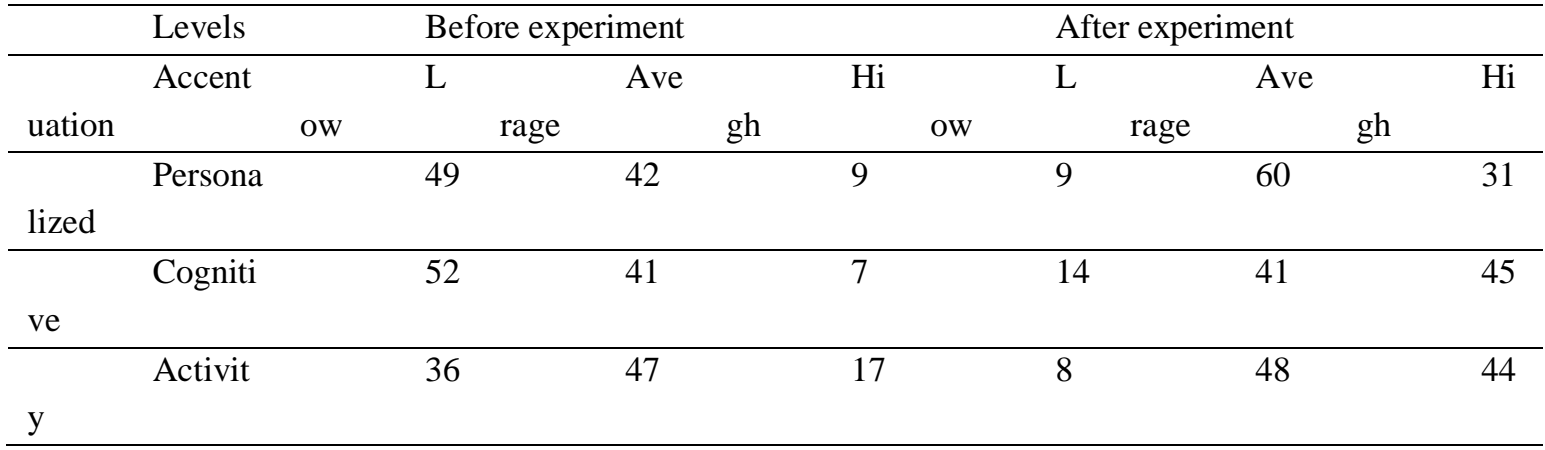


According to Table 3, it can be seen that there is a positive trend in accentuations - changes in the number of students with the highest level of personality-oriented knowledge and skills, which was $31 \%$, which is more than $22 \%$ higher than before the experiment.

Cognitive accentuation $-45 \%$, which is $38 \%$ higher than before the experiment. Activity $-44 \%$, which is $27 \%$ higher than before the experiment. The levels were assessed using psychometric methods (a set of tests and questionnaires), the answers to which were generalized by the experts using mathematical processing methods.

\section{Conclusion}

The results obtained in the course of the study made it possible to draw conclusions on the use of the functional mechanism for technological teacher training update at the universities: (1) the functional mechanism should be understood as an organizational and pedagogical system of actions, a package of measures (with its goals, criteria and means); (2) the mechanism structure should ensure the implementation of the functions of monitoring, conceptualization, informatization and gamification, systematization and classification, forecasting and synergistic analysis, reflection, feedback, continuity, etc.; (3) it is better to check the effectiveness of the functional mechanism not only according the formal indicators of technological equipment of pedagogical education (number of computers, interactive equipment, etc.), but on the basis of criteria (personalized accentuation, cognitive accentuation, activity accentuation, employer satisfaction with training outcomes).

\section{References}

Barnes, N. G., \& Mattson, E. (2010). Social media and college admissions: Higher-ed beats business in adoption of new tools for third year. University of Massachusetts-Dartmouth Center for Marketing Research. Retrieved from http://www.umassd.edu/media/umassdartmouth/ $\mathrm{cmr} / \mathrm{studiesandresearch/socialmediaadmissions.pdf}$

Bloom, B. (1956). Taxonomy of Educational Objectives: Handbook I. The Cognitive Domain. New York: David McKay.

Cunningham, I. (2010). Learning to lead-self managed learning and how academics resist understanding the process. Development and Learning in Organizations: An International Journal, 24(2), 4-6.

Darling-Hammond, L. (2016). Research on teaching and teacher education and its influences on policy and practice. Educational Researcher, 45(2), 83-91.

Garri, H. (2014). Konkuriruya za budushchee. Sozdanie rynkov zavtrashnego dnya [Competing for the future. Creating the markets of tomorrow] [PDF]. Retrieved from https://businessoppurtunities.com/wp-content/uploads/files/conc4future.pdf

Gay, G., \& Howard, T. C. (2000). Multicultural teacher education for the 21st century. The Teacher Educator, 36(1), 1-16.

Hsu, J., Hamilton, K., \& Wang, J. (2014). Guided independent learning: a teaching and learning approach for adult learners. International Journal of Innovation and Learning, 17(1), 111-133.

Ivochkina, T. N. (2012). Nauchno-pedagogicheskoe soprovozhdenie - mekhanizm realizacii strategii razvitiya ob-razovatel'nogo uchrezhdeniya [Scientific and pedagogical support - a mechanism for implementing the development strategy of an educational institution]. Problemy sovremennogo obrazovaniya, 3, 104-109.

Konoplyanskiy, D. A. (2018). Mekhanizmy realizatsii pedagogicheskoy strategii formirovaniya 
konkurento-sposobnosti vypusknika vuza $\mathrm{v}$ usloviyakh reformirovaniya vysshey shkoly [Mechanisms for the implementation of the pedagogical strategy of formation of competition-the possibility of graduation under the conditions of reforming higher education]. Izvestiya Vladimirskogo gosudarstvennogo pedagogicheskogo universiteta, 5, 58-63. Retrieved from mehanizmy-realizatsii-pedagogicheskoy-strategii-formirovaniya-konkurentosposobnostivypusknika-vuza-v-usloviyah-reformirovaniya.pdf

Korpachev, V. V. (2018, December 12). Deyatel'nostnye mekhanizmy professional'nogo razvitiya [Activity mechanisms of professional development] [HTML]. Retrieved from https://nsportal.ru/shkola/obshchepedagogicheskie-tekhnologii/library/2014/11/09/deyatelnostnyemekhanizmy

Loktyushina, E. A. (2011). Formirovanie psihologicheskih mekhanizmov professional'noj inoyazychnoj kompeten-tnosti specialista [Formation of psychological mechanisms of professional foreign language competence-specialist]. Izvestiya Volgogradskogo gosudarstvennogo pedagogicheskogo universiteta, 1(55), 35-38.

Mardahaev, L. V., \& Nikitina, N. I. (2012). Sovremennye pedagogicheskie paradigmy nepreryvnogo professio-nal'nogo obrazovaniya specialistov social'noj sfery $\mathrm{v}$ universitetskom komplekse [Modern pedagogical paradigms of continuous professional-national education of social specialists in the university complex]. Vestnik Sibirskoj gosudarstvennoj avtomobil'no-dorozhnoj akademii, 2(24), 146-152. Retrieved from http://vestnik2.sibadi.org/wpcontent/uploads/2016/10/release-2-2012.pdf

McMahon, M., Forde, C., \& Dickson, B. (2015). Reshaping teacher education through the professional continuum. Educational Review, 67(2), 158-178.

Menter, I. (2015). Teacher Education. In J. D. Wright (Ed.), International Encyclopedia of the Social \& Behavioral Sciences (pp. 51-55). Oxford: Elsevier.

Mityaeva, A. M., \& Fomina, S. N. (2016). Tekhnologicheskoe obespechenie realizacii modeli professional'noj pod-gotovki specialistov po rabote s molodezh'yu [Technological support for the implementation of models of professional training of specialists working with young people]. Uchenye zapiski Orlovskogo gosudarstvennogo universiteta, 1(70), 226-231. Retrieved from http://oreluniver.ru/public/file/archive/201603.pdf

Prigozhin, A. I. (1995). Sotsiologiya organizatsii. Moskva: Interpraks.

Root-Bernstein, R. (2015). Arts and crafts as adjuncts to STEM education to foster creativity in gifted and talented students. Asia Pacific Education Review, 16(2), 203-212.

Shumilova, E. A. (2009). Realizaciya mekhanizmov formirovaniya social'no-kommunikativnoj kompetentnosti v us-loviyah pedagogicheskogo vuza [The implementation of mechanisms for the formation of socio-communicative competence in the conditions of a pedagogical university]. Sovremennaya vysshaya shkola: innovacionnyj aspect, 2, 18-24.

Torgunskaya, N. L. (2007). Usloviya i mekhanizmy realizacii pedagogicheskih innovacij v obrazovanii [Conditions and mechanisms of implementation of pedagogical innovations in education]. Izvestiya Rossijskogo gosudarstvennogo pedagogicheskogo universiteta im. A.I.Gercena, 32(11), 400-403.

Weber, L. E. (2014). Who is responsible for providing and paying for higher educatlon? Preparing the World's Research Universities to Respond to an Era of Challenges and Change (title in blue), 91101. 
Xin, J. F., Accardo, A. L., Shuff, M., Cormier, M., \& Doorman, D. (2016). Integrating global content into special education teacher preparation programs. Teacher Education and Special Education, 39(3), 165-175. 